JOTE Volume 2 Nomor 1 Tahun 2020 Halaman 101-117 JOURNAL ON TEACHER EDUCATION

Research \& Learning in Faculty of Education

\title{
EFEKTIVITAS IMPLEMENTASI METODE PROBLEM BASED LEARNING PADA PEMBELAJARAN MENULIS KARANGAN ARGUMENTASI BAGI SISWA KELAS X SMK NEGERI 2 MAUMERE
}

\author{
Silvester Gudu \\ Guru Bahasa Indonesia Pada SMK Negeri 2 Maumere, Flores, NTT \\ Email : gudusilvester67@gmail.com
}

\begin{abstract}
Abstrak
Penelitian ini bertujuan untuk mengetahui sejauh mana efektivitas metode problem based learning dalam keterampilan menulis karangan argumentasi siswa kelas X SMK Negeri 2 Maumere. Jenis penelitian ini adalah penelitian eksperimen semu. Desain dalam penelitian ini menggunakan non-equivalent control group design. Pendekatan yang digunakan dalam penelitian ini adalah pendekatan deskriptif kuantitatif. Teknik analisi data diolah dengan perhitungan statistik SPSS 16 untuk uji normalitas, homogenitas dan uji-t. Data dalam penelitian ini berdistribusi normal dan homogen. Pada teknik pengumpulan data, diperoleh dengan observasi guru dan melakukan tes. Subjek dari penelitian ini adalah siswa kelas X sebanyak 63 siswa. Hasil penelitian ini menunjukkan bahwa metode problem based learning efektif diterapkan pada pembelajaran bahasa Indonesia khususnya keterampilan menulis. Efektivitas penerapannya dibuktikan dengan hasil t hitung sebesar 7.413 dengan df 29. Uji-t menunjukkan, bahwa t hitung $7.413>0,05$. $t$ hitung kemudian dikonsultasikan dengan nilai $t$ tabel dengan taraf signifikasi 0,05 dan df 29 (n-1). Hasil yang didapat berdasarkan $\mathrm{t}$ tabel adalah sebesar 3.009, hal tersebut menunjukkan bahwa $\mathrm{t}$ hitung >t tabel $(7.413>3.009)$ yang berarti hipotesis diterima. Kesimpulan ada perbedaan kemampuan awal dan akhir menulis karangan argumentasi antara metode guru dan metode problem based learning pada kelas kontrol dan kelas eksperimen. Dapat dibuktikan juga dengan melihat hasil persentase nilai pascates keterampilan menulis karangan argumentasi dengan menerapkan metode guru yaitu $75 \%$, sedangkan persentase nilai pascates keterampilan menulis karangan argumentasi siswa dengan mengimplementasikan metode PBL adalah $80 \%$.
\end{abstract}

Kata kunci: Menulis karangan argumentasi, Metode Problem Based Learning.

\section{Abstract}

This study aims to determine the extent of the effectiveness of the problem-based learning method in the argumentation writing skills of class $X$ students of SMK Negeri 2 Maumere. This type of research is quasi-experimental research. The design in this study used a non-equivalent control group design. The approach used in this research is a quantitative descriptive approach. The data analysis technique was processed with SPSS 16 statistical calculations for the test of normality, homogeneity and t-test. The data in this study were normally distributed and homogeneous. In data collection techniques, obtained by teacher observation and conducting tests. The subjects of this study were 63 students of class $X$. The results of this study indicate that the problem-based learning method 
is effectively applied to Indonesian language learning, especially writing skills. The effectiveness of its application is proven by the results of t count of 7,413 with df of 29. The t-test shows that $t$ count of $7,413>0.05$. $t$ count was then consulted with the t table value with a significance level of 0.05 and df 29 (n-1). The results obtained based on t table amounted to 3.009, this shows that $t$ count $>$ t table $(7,413>3,009)$, which means that the hypothesis is accepted. The conclusion is that there are differences in the initial and final abilities of writing arguments between the teacher method and the problem-based learning method in the control class and the experimental class. It can also be proven by looking at the results of the percentage value of the post-test score of argumentation essay writing skills by applying the teacher's method, which is $75 \%$, while the percentage of students' post-test scores for argumentative essay writing skills by implementing the PBL method is $80 \%$.

Keywords: Writing arguments, Problem Based Learning Method.

\section{PENDAHULUAN}

Menulis adalah salah satu keterampilan berbahasa yang tertinggi. Oleh sebab itu, keterampilan menulis dianggap sebagai suatu keterampilan berbahasa yang sulit. Akibatnya, banyak siswa mengalami kesulitan dalam keterampilan menulis. Siswa dapat dikatakan terampil menulis apabila mampu menyampaikan gagasan berupa pikiran, pendapat, dan perasaan kepada orang lain melalui media tulisan, sehingga apabila orang lain yang membaca dapat menangkap gagasan yang dituliskan secara akurat, benar, dan lengkap.

Pembelajaran menulis di sekolah-sekolah masih sering dianggap sebagai kegiatan yang sulit bahkan dijadikan suatu beban bagi setiap siswa. Faktor yang menjadi suatu masalah bagi siswa untuk menuangkan gagasannya dalam bentuk tulisan, yaitu karena kurangnya motivasi untuk menulis, siswa belum mampu berpikir kritis, dan juga adanya perasaan takut gagal dalam menulis. Namun, kesulitan untuk menulis terutama bersumber pada kurangnya kemampuan seseorang untuk berpikir kritis. Alasan mengapa berpikir kritis dalam menulis itu penting karena seseorang yang tidak dapat berpikir kritis dengan sendirinya tidak dapat mengidentifikasi dan memilah-milah persoalan dengan baik. Hal tersebut men- jadikan siswa sulit untuk menuangkan gagasannya dalam bentuk paragraf. Dalam mengungkapkan suatu gagasan, siswa diharapkan dapat berpikir kritis dan logis. Berpikir kritis sangat dibutuhkan ketika seseorang ingin menganalisis suatu masa- lah yang akan disajikan dalam bentuk teks argumentasi.

Adanya keragaman metode pembelajaran yang diimplementasikan guru menuntut kreativitas seorang guru dalam menerapkan metode pembelajaran yang tepat agar memudahkan siswa untuk mengembangkan keterampilan menulis. Solusi untuk menyelesaikan problematika ini adalah dengan mengimplementasikan metode problem based learning dalam keterampilan menulis karangan argumentasi. Metode problem based learning adalah suatu metode yang tepat untuk membantu siswa mengembangkan keterampilan menulis dalam karangan argumentasi. Oleh karena itu, metode problem based learning merupakan sebuah metode pembelajaran yang menyajikan masalah kontekstual, sehingga merangsang peserta didik untukbelajar.

Berkaitan dengan hal ini, peneliti ingin mencoba melakukan penelitian tentang penerapan metode problem based learning dalam keterampilan menulis karangan argumentasi pada pembelajaran bahasa Indonesia di sekolah-sekolah 
yang ber- notabene sebagai tolak ukur untuk meningkatkan keterampilan berbahasa dalam aspek menulis.

\section{METODE}

Pendekatan yang digunakan dalam penelitian ini adalah pendekatan deskriptif kuantitatif. Penelitian yang menggunakan pendekatan kuantitatif adalah penelitian yang menekankan analisisnya pada data-data numerical (angka) yang diolah dengan metode statistik. Penelitian dengan menggunakan pendekatan kuantitatif akan diperoleh signifikasi perbedaan kelompok atau signifikasi hubungan antara variabel yang satu dengan variabel yang lain (Saifuddin, 20012:5).

Jenis penelitian yang digunakan peneliti ini adalah eksperimen semu. Bentuk penelitian ini banyak digunakan dalam bidang pendidikan. Penelitian eksperimen semu dilakukan untuk menguji hipotesis untuk melihat ada tidaknya pengaruh suatu perlakuan bila dibandingkan dengan pengaruh perlakuan lain yang mengontrol variabelnya disesuaikan dengan kondisi yang ada (situational).

Penelitian eksperimen semu ini menggunakan desain pretest-posttest kelompok kontrol yang non-ekuivalen (Non-equivalent Pretest-Posttest Control Group Design). Desain penelitian pretest-posttest kelompok kontrol yang nonekuivalen, yaitu jenis desain yang pada umumnya digunakan pada penelitian dengan melibatkan kelas-kelas yang sudah ada sebagai kelompoknya, kemudian memilih kelas-kelas yang diperkirakan sama kondisinya. Dalam desain ini terdapat dua kelompok, yaitu satu kelompok sebagai kelompok kontrol dan satu kelompok lagi sebagai kelompok eksperimen. Kelompok eksperimen diberikan perlakuan di dalam kelas dengan mengimplementasikan metode Problem Based Learning dan perlakuan metode guru pada kelompok kontrol. Penentuan kelompok kontrol dan kelompok eksperimen adalah berdasarkan pada karakter kelas di SMK Negeri 2 Maumere. Berikut komponen-komponen perlakuan pada kelompok kontrol dan kelompokeksperimen.

Tabel 1. Komponen Perlakuan

\begin{tabular}{ccc}
\hline Kelompok Kontrol & Komponen & $\begin{array}{c}\text { Kelompok } \\
\text { Eksperimental }\end{array}$ \\
\hline X -1 & Kelas & X -2 \\
\hline 30 siswa & Jumlah Siswa & 33 siswa \\
\hline Metode guru & $\begin{array}{c}\text { Perlakuan Metode } \\
\text { Pembelajaran }\end{array}$ & $\begin{array}{c}\text { Metode Problem } \\
\text { Based Learning }\end{array}$ \\
\hline
\end{tabular}

Adapun desain penelitiannya mengadaptasi dari Emzir (2008:105), yang digambarkan sebagai berikut : 
Tabel 2. Non-equivalen Control Group Design

\begin{tabular}{lccc}
\hline Kelompok & Pretest & Perlakuan & $\begin{array}{l}\text { Post- } \\
\text { test }\end{array}$ \\
\hline Eksperimen & $\mathrm{O} 1$ & $\mathrm{X}$ & $\mathrm{O} 2$ \\
\hline Kontrol & $\mathrm{O} 3$ & - & $\mathrm{O} 4$ \\
\hline
\end{tabular}

Keterangan :

$\mathrm{X}=$ Perlakuan implementasi metode Problem Based Learning

$\mathrm{O} 1=$ keterampilan menulis karangan argumentasi awal pada kelompok eskperimen dengan metode Problem Based Learning.

O2=keterampilan menulis karangan argumentasi akhir pada kelompok eskperimen dengan metode Problem Based Learning.

O3 = keterampilan menulis karangan argumentasi awal pada kelompok kontrol dengan metodeguru.

O4 = keterampilan menulis karangan argumentasi akhir pada kelompok kontrol dengan metodeguru.

Materi dan pokok bahasan yang diberikan pada kelompok kontrol dan kelompok eksperimen adalah sama, hanya saja metode pembelajarannya yang berbeda. Pada kelompok kontrol diajarkan materi menulis karangan argumentasi dengan metode guru yaitu ceramah singkat, diskusi yang difokuskan pada siswa tanpa pendampingan lebih intensif, sedangkan pembelajaran menulis karangan argumentasi pada kelompok eksperimen mengimplementasikan metode Problem Based Learning dengan menekankan pada pendampingan personal untuk memecahkan masalah yang menjadi hambatan siswa.

Adapun langkah-langkahpenelitian adalah sebagai berikut :

1. Tahap Pertama, Pre EksperimenMeasurement

Sebelum melaksanakan tindakan, peneliti terlebih dahulu harus melakukan observasi pada guru yang mengajar di dalam kelas. Membahas mengenai metode pembelajaran yang biasa diterapkan, karakteristik siswa kelas X SMK Negeri 2 Maumere, dan respon siswa terhadap pembelajaran bahasa Indonesia khususnya keterampilan menulis. Peneliti juga mengukurketerampilan awal menulis siswa dengan prates, baik dari kelompok kontrol maupun kelompok eksperimen.

2. Tahap Kedua,Treatment

Tahap kedua dari penelitian ini adalah perlakuan atau treatment dengan mengajar siswa kelas $X-1$ dan $X-2$. Peneliti mengimplementasikan metode pembelajaran berbasis masalah dalam kelas $\mathrm{X}-2$ pada kegiatan pembelajaran menulis karangan argumentasi, dan menggunakan metode guru dalam kelas $X-1$. Dalam penelitian ini, treatment atau ekperimen dilakukan sebanyak 2 kali, 1 kali dengan menerapkan metode guru, dan 1 kali dengan menerapkan metode pembelajaran berbasis masalah. Waktu yang diberikan dari setiap kegiatan $3 \times 45$ menit.

3. Tahap Ketiga, Post EksperimentMeasurement 
Tahap ketiga ini adalah post eksperiment sekaligus tahap terakhir dalam penelitian. Tahap ini diberikan pascates dengan menerapkan metode pembela- jaran berbasis masalah dalam menulis karangan argumentasi. Bentuk soal sa- ma antara kelas X-1dan X-2. Hasil dari nilai pascates digunakan untuk mengetahui akibat pengaruh treatment.

Populasi adalah wilayah generalisasi yang terdiri atas objek atau subjek yang mempunyai kualitas dan karakteristik tertentu yangditetapkan oleh peneliti untuk dipelajari dan kemudian ditarik kesimpulan. Populasi dalam penelitian ini adalah siswa kelas X SMK Negeri 2 Maumere Tahun Ajaran 2017/2018.

Teknik pengambilan sampel dalam penelitian ini adalah teknik cluster sampling, yaitu teknik pengambilan sampel bukan berdasarkan pada individual, tetapi lebih berdasarkan kelompok, daerah atau kelompok subjek yang secara alami berkumpul bersama. Atas persetujuan antara penulis dan guru bahasa Indonesia, peneliti diizinkan kelas $\mathrm{X}-1$ sebagai kelas kontrol dan $\mathrm{X}-2$ sebagai kelas eksperimen dengan jumlah seluruh sampel adalah 63 siswa.

Alasan dipilih kelas X-2 sebagai kelas eksperimen adalah berdasarkan informasi dari guru mata pelajaran Bahasa Indonesia, keterampilan menulis siswa kelas X-2 SMK Negeri 2 Maumere masih rendah karena masih banyak siswa yang belum mendapat nilai sesuai standar yang ditetapkan dan kelas ini tidak semua siswa aktif dalam pembelajaran, masih banyak siswa yang kurang aktif dalam mengikuti pembelajaran, se- dangkan alasan dipilih kelas X-1 menjadi kelas kontrol adalah ber- dasarkan informasi dari guru mata pelajaran bahasa Indonesia, kelas X-1 hampir semua siswa aktif terlibat dalam pembelajaran dan mere- ka termasuk siswa yang kritis dalam berpikir ketika mengungkapkan suatu ga- gasan atau sanggahan ketika diskusi dikelas.

Variabel penelitian adalah objek yang diteliti dan dipelajari kemudian ditarik kesimpulan atau apa yang menjadi titik pusat suatu penelitian. Terdapat dua variabel dalam penelitian ini, yaitu: (1) Variabel bebas adalah variabel yang memengaruhi atau yang menjadi sebab perubahan atau timbulnya variabel terikat.Variabel bebas dalam penelitian ini adalah implementasi metode Problem BasedLearning; (2) Variabel terikat merupakan variabel yang dipengaruhi atau yang menjadi akibat karena adanya variabel bebas. Dalam penelitian ini variabel terikatnya adalah peningkatan keterampilan menulis karangan argumentasi siswa.

Adapun teknik pengumpulandata dalam penelitian ini sebagai berikut : Observasi

Observasi menurut Hadi (dalam Sugiyono, 2014:145) mengemukakan bahwa observasi merupakan suatu proses yang kompleks, suatu proses yang tersusun dari berbagai biologis dan psikologis, sehingga observasi tidak hanya dilakukan pada makhluk hidup, melainkan juga pada objek alam yang lainnya. Observasi ini dilakukan untuk mengetahui seberapa jauh pengaruh metode pembelajaran problem based learning dalam keterampilan menulis karangan argumentasi.

Observasi yang dilakukan adalah observasi langsung, yang mana observasi dilakukan secara langsung terhadap objek yang diselidiki. Observasi 
langsungdilakukan dengan mengamati aktivitas guru ketika mengajar di kelas dan mengamati aktivitas siswa ketika belajar di kelas, sehingga peneliti mengetahui karakteristik siswa yang akan diteliti.

\section{HASIL DAN PEMBAHASAN}

\section{Teknik Analisis Data}

Analisis data untuk uji hipotesis ini dilakukan dengan membandingkan nilai pascates kelas kontrol dan pascates kelas eksperimen menggunakan uji-t pada SPSS 16. Pengujian hipotesis dilakukan dengan teknik uji statistik yang cocok dengan distribusi data yang diperoleh. Proses pengujian hipotesis akan meliputi uji normalitas dan uji homogenitas varian sebagai syarat untuk menggunakan statistic parametric, dan dengan menggunakan uji-t. Di bawah ini adalah hasil teknik analasis data menggunakan SPSS 16.

Uji Normalitas

Uji normalitas dilakukan untuk mengetahui apakah data berasal dari populasi yang berdistribusi normal atau tidak. Pada penelitian ini data diasumsikan berdistribusi normal atau tidak. Perhitungannya dibuktikan menggunakan uji One-Sample Kolomogorov-Sminorv pada program SPSS 16.

Tabel 3. Uji Normalitas Prates Kelas Kontrol

\begin{tabular}{|l|l|r|}
\hline \multicolumn{2}{|c|}{ One-Sample Kolmogorov-Smirnov Test } \\
\hline \multirow{2}{*}{} & & \multicolumn{2}{l|}{$\begin{array}{l}\text { Nilai Prates } \\
\text { Kelas } \\
\text { Kontrol }\end{array}$} \\
\hline N & & 30 \\
\hline Normal Parameters ${ }^{\text {a }}$ & Mean & 65.20 \\
\cline { 2 - 4 } & Std. Deviation & 10.220 \\
\hline Most Extreme Differ- & Absolute & .215 \\
\cline { 2 - 4 } ences & Positive & .185 \\
\cline { 2 - 4 } & Negative & -.215 \\
\hline Kolmogorov-Smirnov Z & 1.176 \\
\hline Asymp. Sig. (2-tailed) & .126 \\
\hline
\end{tabular}

Test distribution is Normal.

Uji Normalitas Prates Kelas Kontrol

Uji normalitas data dikatakan berdistribusi normal apabila hasil di- peroleh pada Asymp. Sig. (2-tailed) >0,05. Dalam tabel uji normalitas prates kelas kontrol diketahui bahwa data berdistribusi normal. Hal ter- sebut dibuktikan dengan melihat hasil Asymp. Sig. (2-tailed) pada tabel 5 adalah 0,126 atau dapat 
dikatakan bahwa hasil Asymp. Sig. (2- tailed) pada tabel 5 menunjukkan hasil $>0,05$. Perhitungan data di- buktikan menggunakan uji One-Sample Kolomogorov-Sminorv pada program SPSS16.

Tabel 4. Uji Normalitas Pascates Kelas Kontrol One-SampleKolmogorov-

\begin{tabular}{|c|c|c|}
\hline & intmoviest & $\begin{array}{l}\text { Nitaifaseates } \\
\text { Kelas Kontrol }\end{array}$ \\
\hline \multicolumn{2}{|l|}{$\mathrm{N}$} & 30 \\
\hline \multirow[t]{3}{*}{ NormalParameters $^{\mathrm{a}}$} & Mean & 74.80 \\
\hline & Std. Deviation & 10.420 \\
\hline & Absolute & .308 \\
\hline \multirow{2}{*}{$\begin{array}{l}\text { MostExtremeDiffer- } \\
\text { ences }\end{array}$} & Positive & .164 \\
\hline & Negative & -.308 \\
\hline \multirow{2}{*}{\multicolumn{2}{|c|}{$\begin{array}{l}\text { Kolmogorov-Smirnov Z } \\
\text { Asymp. Sig. (2-tailed) }\end{array}$}} & 1.685 \\
\hline & & .007 \\
\hline \multicolumn{2}{|c|}{ Test distribution is Normal. } & \\
\hline
\end{tabular}

Uji Normalitas Pascates Kelas Kontrol

Dalam tabel uji normalitas pascates kelas kontrol diketahui bahwa data juga berdistribusi normal. Hal tersebut dibuktikan dengan melihat hasil Asymp. Sig. (2-tailed) pada tabel 6 adalah 0,07 atau dapat dikatakan bahwa hasil Asymp. Sig. (2-tailed) pada tabel 6 menunjukkan hasil $>0,05$. Perhitungan data dibuktikan menggunakan uji One-Sample Kolomogorov-Sminorv pada program SPSS 16

tabel 5. UJi Normalitas Prates Kelas Eksperimen One-Sample KOLMOGOROV-SMIRNOV TEST

\begin{tabular}{|ll|r|}
\hline & & $\begin{array}{r}\text { Nilai Prates Kelas } \\
\text { Eksperimen }\end{array}$ \\
\hline NormalParameters & \\
& & Mean \\
MostExtremeDiffer- & Std. Deviation & 76.00 \\
ences & Absolute & 6.913 \\
& Positive & .352 \\
& Negative & .235 \\
Kolmogorov-Smirnov Z & -.352 \\
\hline Asymp. Sig. (2-tailed) & & 1.927 \\
\hline
\end{tabular}

Uji Normalitas Prates KelasEksperimen

Dalam tabel uji normalitas prates kelas eksperimen diketahui bahwa data berdistribusi normal. Hal tersebut dibuktikan dengan melihat hasil Asymp. Sig. (2tailed) pada tabel 7 adalah 0,057 atau dapat dikatakan bahwa hasil Asymp. Sig. (2-tailed) pada tabel 7 menunjuk- kan hasil $>0,05$. Perhitungan data dibuktikan menggunakan uji One-Sample Kolomogorov-Sminorv pada program SPSS16. 
Tabel 6. Uji Normalitas Pascates Kelas Eksperimen One-Sample Kolmogorov Smirnov Test

\begin{tabular}{|ll|r|}
\hline & & $\begin{array}{r}\text { Nilai Pascates } \\
\text { KelasEksperimen }\end{array}$ \\
\hline $\mathrm{N}$ & & 30 \\
Normal Parameters ${ }^{\mathrm{a}}$ & Mean & 79.53 \\
& Std. Deviation & 9.923 \\
Most Extreme Differ- & Absolute & .239 \\
ences & Positive & .239 \\
& Negative & -.143 \\
Kolmogorov-Smirnov Z & & 1.310 \\
\hline Asymp. Sig. (2-tailed) & & .065 \\
\hline
\end{tabular}

Test distribution is Normal.

a. Uji Normalitas Pascates Kelas Eksperimen

Dalam tabel uji normalitas prates kelas eksperimen diketahui bahwa data juga berdistribusi normal. Hal tersebut dibuktikan dengan melihat hasil Asymp. Sig. (2-tailed) pada tabel 8 adalah 0,065 atau dapat dikatakan bahwa hasil Asymp. Sig. (2-tailed) pada tabel 8 menunjukkan hasil $>0,05$. Perhitungan data dibuktikan menggunakan uji One-Sample KolomogorovSminorv pada program SPSS16.

1. Uji HomogenitasVarian

Uji homogenitas varian dilakukan untuk mengetahui apakah sampel yang diambil memiliki varians yang homogen atau tidak. Salah satu teknik statistik yang digunakan untuk menjelaskan homogenitas kelompok adalah dengan varian. Sampel yang digunakan dalam penelitian ini adalah homogen karena nilai signifikannya lebih besar dari 0,05 . Hal ini dibuktikan dengan uji homogenitas varian pada SPSS 16.

\section{TABEL 7. Uji Homogenitas (Test of Homogeneity of Variances)}

\begin{tabular}{|c|c|c|c|}
\hline e Statis- tic & df1 & df2 & Sig. \\
\hline 4.799 & 4 & 25 & .005 \\
\hline
\end{tabular}

Uji-t(t-test)

Langkah yang dilakukan peneliti selanjutnya adalah uji-t setelah normalitas dan homogenitas diketahui. Perhitungan uji-t dilakukan secara statistik menggunakan uji parametrik dengan tipe uji Paired Sample t Test. Berikut adalah perhitungan uji Paired Sample t Test dengan program SPSS 16. 
TABEL 8. Uji-t pada nilai prates pascates kelompok eksperimen dan kontrol

\begin{tabular}{|c|c|c|c|c|c|c|}
\hline \multicolumn{7}{|c|}{ Paired Samples Statistics } \\
\hline & & $\begin{array}{l}\text { Me } \\
\text { an }\end{array}$ & $\mathrm{N}$ & $\begin{array}{l}\text { Std. } \\
\text { De- } \\
\text { viation }\end{array}$ & $\begin{array}{l}\text { td. } \\
\text { Error } \\
\text { Mean }\end{array}$ & $\begin{array}{l}\text { Correlati } \\
\text { on }\end{array}$ \\
\hline \multirow{4}{*}{$\begin{array}{l}\text { Pair } \\
1\end{array}$} & NILAI PRATES & 65. & 3 & 10.220 & 1.866 & \multirow{4}{*}{.674} \\
\hline & KELAS KONTROL & 20 & 0 & & & \\
\hline & NILAI PASCA TES & 74. & 3 & 10.420 & 1.902 & \\
\hline & KELAS KONTROL & 80 & 0 & & & \\
\hline \multirow{6}{*}{$\begin{array}{l}\text { Pair } \\
2\end{array}$} & NILAI PRATES & 76. & 3 & 6.913 & 1.262 & \multirow{6}{*}{.764} \\
\hline & KELAS & 00 & 0 & & & \\
\hline & EKSPERIMEN & & & & & \\
\hline & NILAI PASCA TES & & & & & \\
\hline & KELAS & 79. & 3 & 9.923 & 1.812 & \\
\hline & EKSPERIMEN & 53 & 0 & & & \\
\hline
\end{tabular}

Paired Samples Test

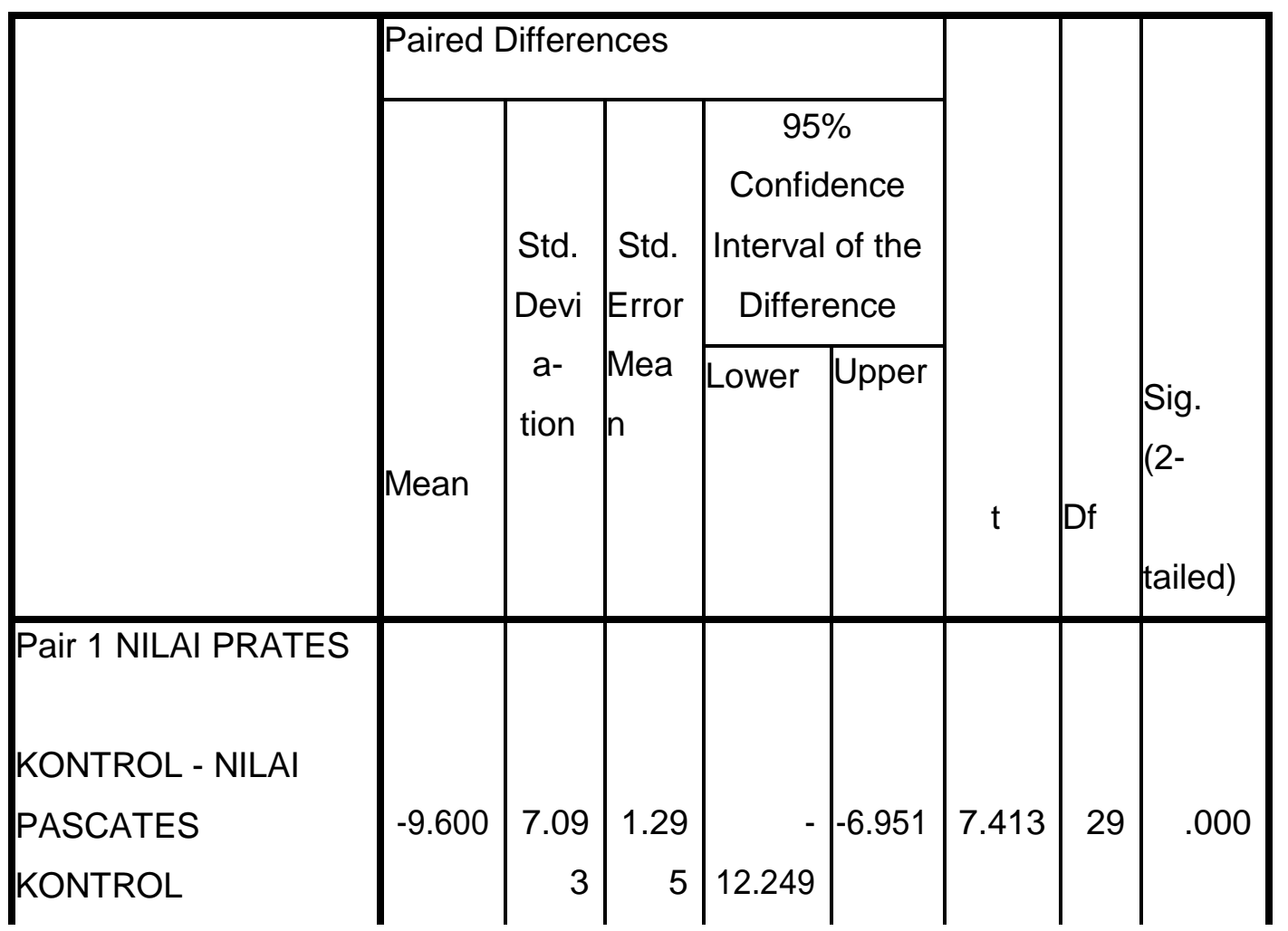




\begin{tabular}{|l|r|r|r|r|r|r|r|r|} 
Pair 2 NILAI PRATES & & & & & & & & \\
EKSPERIMEN - NILAI & & & & & & & & \\
PASCATES & -2.533 & 7.33 & 1.34 & -5.273 & .207 & 1.891 & 29 & .069 \\
EKSPERIMEN & & 8 & 0 & & & & & \\
\hline
\end{tabular}

Berdasarkan tabel di atas dapat diketahui t hitung $>t$ tabel. Hal tersebut menunjukkan bahwa hasil t hitung sebesar 7.413 dengan df 29. Uji-t menunjukkan, bahwa t hitung $>0,05(7.413>0,05)$. t hitung kemudian dikonsultasikan dengan nilai t tabel dengan taraf signifikasi 0,05 dan df $29(\mathrm{n}-1)$. Hasil yang didapat berdasarkan t tabel adalah sebesar 3.009, hal tersebut menunjukkan bahwa t hitung $>t$ tabel $(7.413>3.009)$ yang berarti hipotesis diterima. Jadi, dapat disimpulkan bahwa ada perbedaan kemampuan awal dan akhir menulis karangan argumentasi antara metode guru dan metode problem based learning pada kelas kontrol dan kelas eksperimen.

Tabel 9. Uji-t Nilai PascaTes Kelompok Kontrol dan Eksperimen

\begin{tabular}{|l|l|l|l|l|}
\hline KELOMPOK & $\mathrm{N}$ & Mea & $\begin{array}{l}\text { Devia- } \\
\text { tion }\end{array}$ & $\begin{array}{l}\text { d. Error } \\
\text { Mean }\end{array}$ \\
\hline NilaiSiswa Nilai Pascates & 30 & 74.8 & 10.420 & 1.902 \\
Kontrol Pascates Nilai & 30 & 0 & 9.923 & 1.812 \\
PascatesEksperimen & & 79.5 & & \\
\hline
\end{tabular}

Tabel 10 Uji-t Perbedaan Nilai Pasca Tes Kelompok Eksperimen dan Kontrol

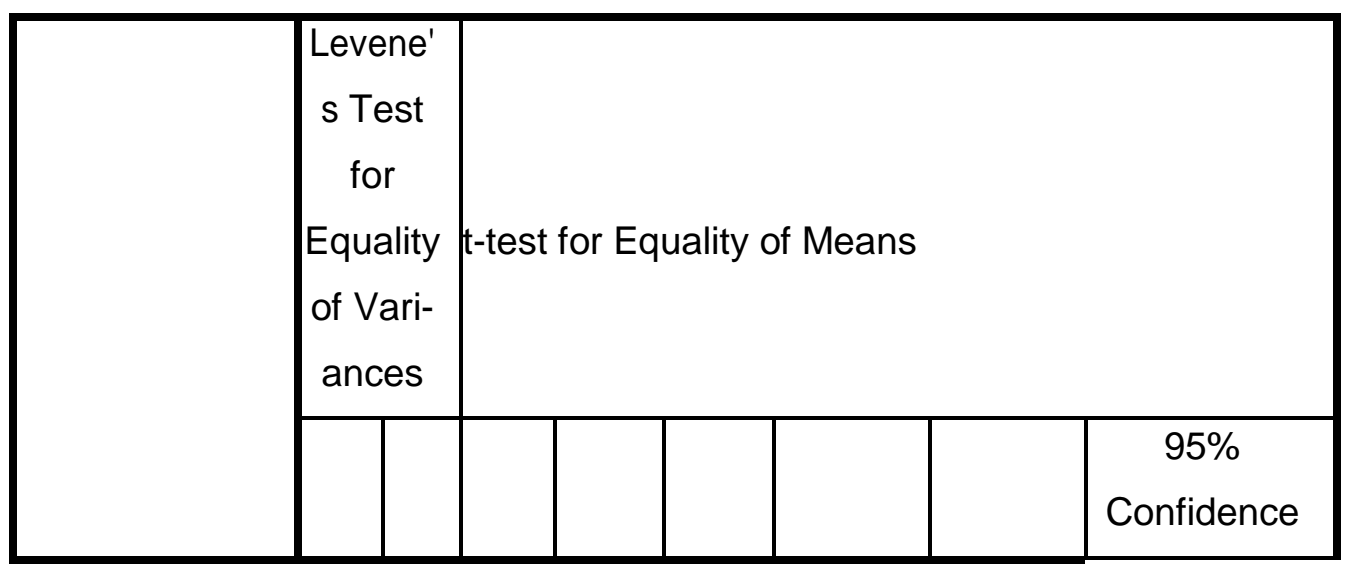




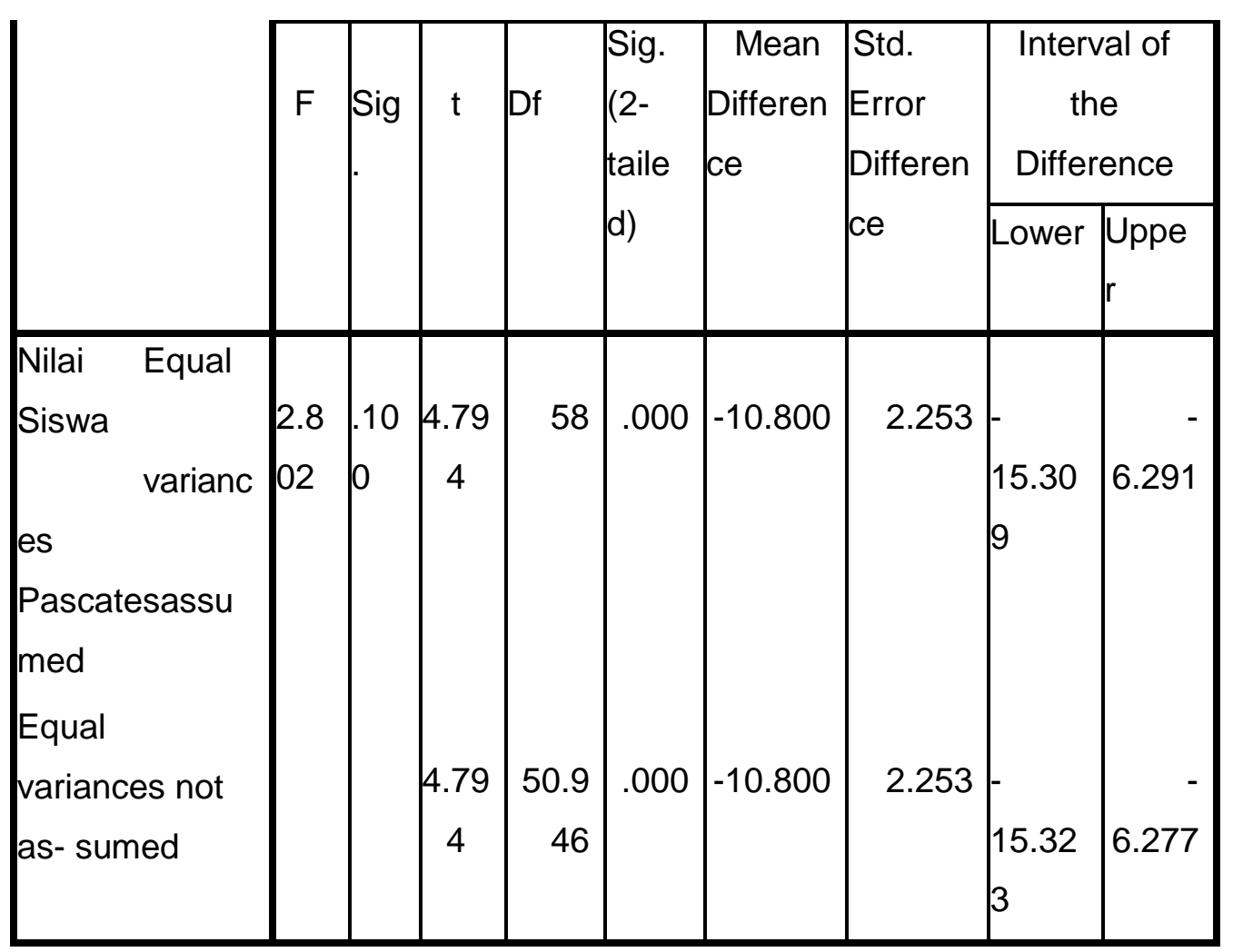

Uji-t digunakan untuk mengetahui pengaruh variabel independen secara parsial terhadap variabel dependen, apakah pengaruhnya signifikan atau tid- ak. Dalam uji-t variabel diperoleh niai t hitung sebesar 4.794 sedangkan nilai t tabel 1.671 diperoleh dari tabel df 58. Dari hasil t hitung dan t tabel dapat diketahui bahwa t hitung (4.794) >tabel (1.671) atau dengan kata lain hipotesis nol ( $\mathrm{Ho})$ diterima. Kesimpulan yaitu metode problem based learning berpengaruh terhadap kemampuan menulis teks argumentasi.

\section{Implementasi Metode Problem BasedLearning}

Berdasarkan pengamatan yang peneliti lakukan pada guru, siswa dan pros- es pembelajaran keterampilan menulis di kelas $\mathrm{X}-1$ dan $\mathrm{X}-2$, dapat diketahui bahwa pembelajaran bahasa Indonesia cenderung masih konvensiaonal sesuai dengan lembar hasil observasi aktivitas guru yang menyatakan bahwa guru tidak pernah memanfaatkan media ataupun alat peraga dalam pembelajaran. Hal ini dapat dilihat dari cara mengajar guru atau metode yang digunakan guru untuk mengajar. Metode pembelajaran yang digunakan oleh guru masih konvensional, kegiatan belajar mengajar di dalam kelas masih berpusat pada guru saja, yaitu guru terlalu banyak menggunakan ceramah dan terkadang menunjuk salah satu siswa untuk membacakan karangan tanpa diberi penguatan. Pemanfaatan media pembelajaran yang mendukug proses pembelajaran pun tidak maksimal. Proses pembelajaran seperti ini tentu saja akan membuat siswa cepat bosan dan peran serta siswa pun cenderung pasif. Guru mengajar dengan konsep kontekstual tetapi kurang diberikan penguatan pada setiap penjelasannya. Meskipun metode mengajar guru konvensional, siswa kelas X-1 dan X-2 SMK Negeri 2 Maumere tetapi aktif, tetapi dalam beberapa materi pembelajaran saja. 
Tahap kedua dari penelitian ini adalah perlakuan atau treatment dengan mengajar siswa kelas X-1 dan X-2. Peneliti mengimplementasikan metode problem based learning dalam kelas $\mathrm{X}-2$ pada kegiatan menulis, dan mengimplementasikaan metode konvensional yaitu ceramah dan diskusi saja sesuai dengan guru yang mengajar dalam kelas $\mathrm{X}-1$. Dalam penelitian ini, treatment dilakukan sebanyak 2 kali, 1 kali dengan menerapkan metode problem based learning, dan 1 kali dengan men- erapkan metode guru. Treatment dilaksanakan dalam waktu 480 menit, 240 menit di kelas $X-1$, dan 240 menit di kelas X-2. Masing- masing treatment dilakukan selama $4 \times 45$ menit. Hasil dari setiap treatment adalah keterampilan menulis karangan argumentasi siswa.

Siswa-siswa kelas X-2 (eksperimen) menyambut baik peneliti dan bersedia untuk mengikuti segala prosedur yang diberikan oleh peneliti. Dalam satu kali pertemuan, peneliti meminta siswa-siswa mengerjakan dua topik yang sudah ditentukan oleh peneliti. Topik yang pertama adalah dampak penggunaan gadget di kalangan remaja dan topik yang kedua adalah dampak media sosial di kalangan pelajar. Langkah-langkah pembelajaran menulis pada pertemuan pertama yang dilakukan peneliti dengan menerapkan metode problem based learning, yaitu sebagai berikut.

a. Fase 1: Orientasi siswa padamasalah

Implikasi dalam pembelajaran awal, peneliti harus bertanya kepada siswa- siswa kelas X-2 tentang masalah perkembangan teknologi sebagai pengantar. Lalu, siswa-siswa menyimak sebuah video dokumentasi yang ditayangkan oleh peneliti sebagai gambaran ilustrasi mengenai masalah perkembangan teknologi. Tujuan peneliti menayangkan sebuah video dokumentasi selain untuk memberi gambaran ilustrasi yaitu untuk memancing siswa-siswa untuk saling mengungkapkan argumennya mengenai masalah perkembangan teknologi saat ini.

b. Fase 2: Mengorganisasikan siswa untukbelajar.

Pada fase ini siswa-siswa diminta untuk mendiskusikan tentang dampak negatif mengenai perkembangan teknologi dalam sebuah kelompok. Setelah siswa berdiskusi dalam kelompoknya, peneliti menegaskan kepada siswa-siwa bahwa tugas siswa adalah menulis karangan argumentasi berdasarkan topik yang sudah ditentukan, yang berarti bahwa siswa-siswa harus mengungkapkan permasalahan mengenai dampak negatif perkembangan teknologi sesuai topik yang sudah ditentukan dengan faktafakta yang terjadi.

c. Fase 3: Membimbingpenyelidikan

Pada fase ini, peneliti membimbing siswa-siswa untuk mengungkapkan gagasan-gagasan dalam kelompok. Pada fase ini juga, peneliti memberi kesempatan kepada siswa-siswa untuk melihat karangan argumentasi dari berbagai sumber.

d. Fase 4: Mengembangkan dan menyajikan hasilkarya

Pada fase ini, peneliti mengajak siswa untuk melakukan editing terhadap karangan yang sudah dibuatnya, baik dari segi pilihan kata maupun 
struktur dan isi karangan argumentasi sampai siswa memahaminya dengan baik.

e. Fase 5: Menganalisis dan mengevaluasi proses pemecahanmasalah

Pada fase terakhir ini, peneliti menunjuk salah satu perwakilan dari kelompok untuk membacakan salah satu hasil karangan argumentasi di depan kelas dan setelah salah satu perwakilan kelompok membacakan salah satu hasil karangan argumentasinya, peneliti bersama siswa-siswa melakukan refleksi terhadap pelaksanaan pembelajaran pada hari itu.

Kegiatan evaluasi ketika mengimplementasikan metode problem based learning dan tanpa mengimplementasikan metode problem based learning menjadi langkah ketiga sekaligus langkah terakhir dalam penelitian ini, yaitu dengan memberikan pascates pada kelompok kontrol dan kelompok eksperimen. Bentuk soal pascates pada kelompok kontrol dan kelompok eksperimen adalah sama. Hasil dari pascates ini berupa data kemampuan akhir siswa yang digunakan untuk mengetahui pengaruh yang ditimbulkan akibat dari pem- berian perlakuan. Pascates dilakukan 1 kali baik pada kelompok kontrol mau- pun kelompok eksperimen untuk mengetahui kemampuan siswa, setelah itu dari kedua pascates dicari nilai rata-ratanya. Hasil dari nilai rata-rata pascates itu adalah nilai akhir keterampilan menulis karangan argumentasi siswa dari kelompok kontrol dan kelompok eksperimen. Berikut adalah diagram nilai ratarata kelas $\mathrm{X}-1$ dan $\mathrm{X}-2$.

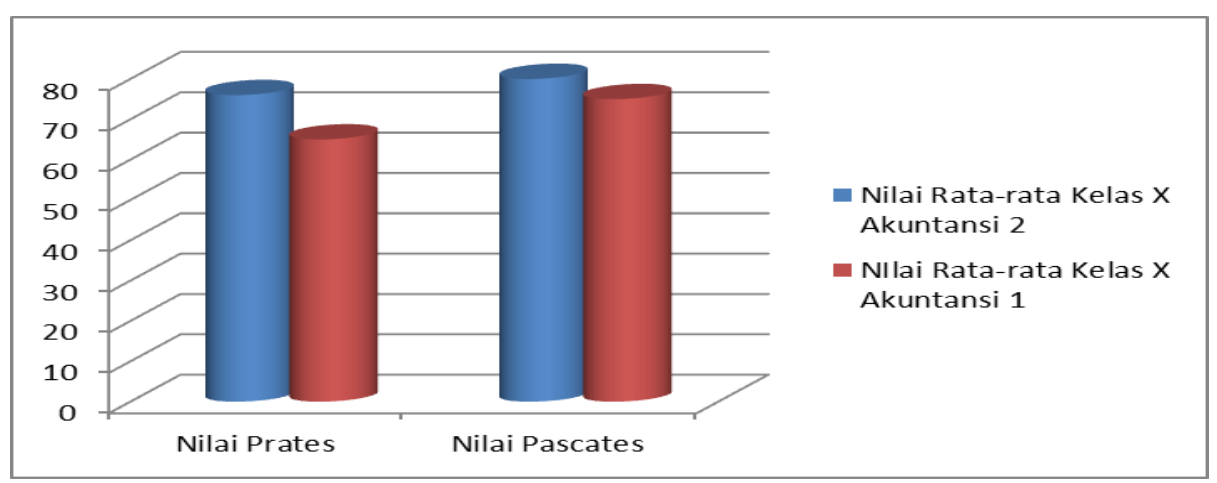

I. Diagram Nilai Rata-Rata Kelas X-1 dan Kelas X-2

Berdasarkan diagram nilai rata-rata keterampilan menulis siswa kelas $\mathrm{X}$ 1 dan X-2 terdapat perbedaan kelas yang signifikan. Perbedaan itu terdapat pada nilai keterampilan menulis siswa dengan men- erapkan metode problem based learning dan tanpa menerapkan metode prob- lem based learning. Apabila peneliti mengambil angka bulat, maka rata-rata nilai keterampilan menulis siswa X -2 yaitu 80 adalah kategori ma- hir pada nilai $80 \%$ dalam PAP Tipe I, sedangkan rata-rata nilai keterampilan menulis siswa kelas $\mathrm{X}-1$ yaitu 75 dalam kategori cukup mahir pada nilai $75 \%$ dalam PAP Tipe I. Perolehan rata-rata nilai keterampilan siswa kelas $\mathrm{X}-1$ menunjukkan tidak ada perubahan yang signifikan dengan kondisi awal. Oleh sebab itu, maka metode problem based learning efektif diimplementasikan pada keterampilan menulis siswa kelas X SMK Negeri 2 Maumere. 


\section{Data Penelitian}

Data penelitian ini terdiri dari dua data, yaitu data observasi/pengamatan guru mengajar dan data penerapan metode problem based learning oleh peneliti.

\section{a. DataObservasi/Pengamatan}

Peneliti melakukan pengamatan sebanyak dua kali. Pada saat kegiatan observasi dilaksanakan peneliti menfokuskan tiga hal yakni aktivitas guru di kelas secara umum berupa pernyataan umum YA atau TIDAK dengan melihat kesiapan guru ketika memulai pembelajaran, melakukan pembelajaran, dan menutup pembelajaran. Sasaran pada fokus pertama itu juga memperhatikan sikap guru yang serius atau santai, sering berjalan mengelilingi kelas atau duduk saja, sering memberikan tugas atau hanya ceramah saja dan lainsebagainya.

Fokus kedua yaitu aktivitas guru dalam melaksanakan interaksi belajar mengajar seperti pembelajaran yang meliputi penguasaan materi pembelajaran, pendekatan, dan teknik yang digunakan, pemanfaatan media pembelajaran yang memicu keterlibatan siswa, penggunaan bahasa, penilaian proses dan hasil belajar, kegiatan akhir pembelajaran meliputi refleksi dan rangkuman pembelajaran serta pelaksanaan tidak lanjut. Selanjutnya fokus terakhir pada aktivitas siswa di kelas berupa pernyataan siswa YA atau TIDAK dengan melihat kesiapan siswa dalam pembelajaran, perhatian, tanggapan, serta tanggung jawab siswa terhadap tugas yang diberikan.

\section{b. Data Treatment Peneliti}

Peneliti mengajar sebanyak 2 kali pertemuan, masing-masing 1 kali pertemuan untuk kelas kontrol yaitu kelas $\mathrm{X}-1$ dan 1 kali untuk ke- las eksperimen yaitu kelas X-2. Pada kelas X-2 peneliti mengajar dengan mengimplementasikan metode problem based learning dan pada kelas X-1 peneliti menerapkan metode dan teknik yang biasa digunakan oleh guru bahasa Indonesia SMK Negeri 2 Maumere.

\begin{tabular}{|l|l|l|l|}
\hline \multicolumn{1}{|c|}{ Materi } & Tanggal & Tempat \\
Pembelajaran & & & \\
\hline Kegiatan menulis & Selasa, 29 & Jam pelajaran & Ruang kelas \\
karangan argumen- & Agustus 2017 & ke 5-8 & X-1 \\
tasi “Dampak & $(10.15-13.00$ & \\
Penggunaan Gadget & & WIB $)$ & \\
di Kalangan Rema- & & & \\
ja" dan "Dampak & & & \\
Media Sosial Di & & & \\
Kalangan Pelajar" & & & \\
\hline
\end{tabular}




\begin{tabular}{|l|l|l|c|}
\hline Kegiatan menulis & Senin, 4Sep- & n pelajaran & Ruang kelas \\
karangan argumen- & tember2017 & ke 2-5 & X -2 \\
tasi "Dampak & $(07.45-10.15)$ & \\
Penggunaan Gadget & & \\
di Kalangan Rema- & & \\
ja" dan “Dampak & & \\
Media Sosial Di & & \\
Kalangan Pelajar" & & & \\
\hline
\end{tabular}

\section{SIMPULAN}

Penelitian eksperimen ini berlangsung dalam dua kali tatap muka di dalam kelas. Satu kali tatap muka di dalam kelas sesuai dengan alokasi waktu berdasarkan Kurikulum 2013, yaitu 4 JP (4 x 45 menit). Penelitian ini dilakukan di kelas X -1 dan X-2 SMK Negeri 2 Maumere pada bulan Agustus-September 2017. Tujuan dari penelitian ini adalah yang pertama untuk mengetahui hasil kemampuan menulis prates kelas kontrol, yang kedua untuk mengetahui hasil kemampuan menulis pascates kelas eksperimen, dn yang ketiga untuk mengetahui efektivitas implementasi metode problem based learning dalam keterampilan menulis pada pembelajaran bahasa Indonesia siswa kelas X SMK Negeri 2 Maumere Tahun Ajaran 2017/2018.

Berdasarkan hasil penelitian yang telah dilakukan peneliti, dapat disimpulkan bahwa metode problem based learning efektif diterapkan pada pembelajaran ba- hasa Indonesia khususnya keterampilan menulis. Efektivitas penerapannya dibuk- tikan dengan nilai signifikasi dalam uji-t pada perbedaan nilai pascates kelompok eksperimen dan kelompok kontrol, yaitu 0,10. Hal ini membuktikan bahwa metode problem based learning efektif diterapkan dalam pembelajaranketerampilan menulis teks argumentasi siswa karena nilai t lebih besar dari 0,05 atau dapat juga dibuktikan dengan hasil t hitung sebesar 7.413 dengan df 29. Uji-t menunjukkan, bahwa t hitung $7.413>0,05$. $t$ hitung kemudian dikonsultasikan dengan nilai t tabel dengan taraf signifikasi 0,05 dan df $29(n-1)$. Hasil yang didapat berdasarkan t tabel adalah sebesar 3.009, hal tersebut menunjukkan bahwa $t$ hitung $>t$ tabel $(7.413>3.009)$ yang berarti hipotesis diterima.

Data lain yang mendukung adalah nilai awal keterampilan menulis karangan argumentasi siswa baik dari kelompok kontrol (kelas X-1) maupun kelompok eksperimen (X -2) adalah 75\%. Jika dikategorikan berdasarkan tabel acuan PAP tipe I termasuk dalam kategori cukup mahir dengan rentang skor $65 \%-79 \%$. Kemudian setelah dilakukan pembelajaran dengan menerapkan metode problem based learning, nilai keterampilan menulis karangan argumentasi siswa meningkat dari $75 \%$ menjadi $76 \%$ pada percobaan pertama, sedangkan pada percobaan kedua nilai keterampilan menulis karangan argumentasi siswa mening- kat menjadi $80 \%$. 
Hal ini membuktikan bahwa peningkatan nilai keterampilan menulis karangan argumentasi siswa dengan mengimplementasikan metode problem bassed learning dalam pembelajaran meningkat sebesar $5 \%$, begitu juga dengan perco- baan yang dilakukan peneliti dengan menerapkan metode guru memperoleh nilai $65 \%$, sedangkan pada percobaan kedua dengan menerapkan metode guru juga mengalami peningkatan menjadi 75\%. Akan tetapi, tetap meningkat apabila dibandingkan dengan percobaan yang mengimplementasikan metode problem based learning. Peningkatan nilai pascates keterampilan menulis karangan argumentasi siswa sebesar 5\%. Hasil tersebut menunjukkan bahwa pembelajaran menulis dengan mengimplementasikan metode problem based learning lebih efektif dibandingkan dengan metode guru. Dari hasil peningkatan nilai pascates itu, maka metode problem based learning efektif diimplementasikan dalam pembelajaran keterampilan menulis karangan argumentasi siswa.

\section{DAFTAR PUSTAKA}

Abdul dan Rohman, C. (2014). Pendekatan IImiah dalam Implementasi Kurikulum 2013. Bandung: Remaja Rosdakarya

Alwasilah, A. Chaedar. (2007). Pokoknya Menulis. Bandung: Kiblat. Arifin, Z. (2009). Evaluasi Pembelajaran. Bandung: Remaja Rosdakarya

Browne, M. N. dan Keeley, S. M. (2012). Pemikiran Kritis Panduan untuk Mengajukan dan Menjawab Pertanyaan Kritis. Jakarta: Indeks.

Darma, B. (2007). Bahasa, Sastra dan Budi Dharma. Surabaya: Temprina Media Grafika.

Doyin, Mukh dan Wagiran. (2005). Curah Gagasan: Pengantar Penulisan Karya IImiah. Semarang: Rumah Indonesia.

Emzir. (2008). Metodologi Penelitian Pendidikan Kuantitatif dan Kualitatif. Jakarta: Raja Grafindo Persada.

Izhab, Z. (2003). Hakikat Berpikir Kritis dan Pentingnya Bagi Peserta Didik.http://www.kompasiana.com/awadsajaya/berpikirkritis.

Diunduh 16 November 2015.

Keraf, G. (2000). Argumentasi dan Narasi Komposisi Lanjutan III.Jakarta: Gramedia Pustaka Utama.

Keraf, G. (2007). Argumentasi dan Narasi. Jakarta: Gramedia Pustaka Utama.

Kosasih, E. (2014). Strategi Belajar dan Pembelajaran. Bandung: Yrama Widya

Kurnia, Deka. (2011). "Upaya Meningkatkan Keterampilan Menulis Argumentasi Dengan Menggunakan Metode Jigsaw Pada Siswa Kelas XB SMA Islam 1 Gamping Sleman Yogyakarta". Skripsi. Yogyakarta: Universitas Negeri Yogyakarta.

Kuswana, W. (2011). Taksonomi Berpikir. Bandung: Remaja Rosdyakara. Maulana, Nanang. (2015). "Penggunaan Metode Problem Based Learning Untuk Meningkatkan Kemampuan Menulis Eksposisi dan 
Berpikir Kritis Di SMA". Jurnal Kajian Pendidikan dan Pengajaran 1 (1), 70-76.

Nurgiyantoro, B. (2012). Penelitian Pengembangan Bahasa Berbasis Kompetensi. Yogyakarta: Yogyakarta

Nurjamal, dkk. (2014). Terampil Berbahasa. Bandung: Alfabeta. Nursisto. (1999). Membina Majalah Dinding. Yogyakarta: Adicita KaryaNusa. Nursisto. (2000). Penuntun Mengarang. Yogyakarta: Adicita Karya Nusa. Nurudin. (2007). Dasar-Dasar Penulisan. Malang: UniversitasMuhammadiyah Malang.

Saifuddin, A. (2012). Realibilitas dan Validitas. Yogyakarta: Pustaka Pelajar.

Sanjaya, W. (2008). Strategi Pembelajaran Berorientasi Standar Proses Pendidikan. Jakarta: Kencana Prenada Media Group

Sudaryat, Y. (2009). Makna dalam Wacana. Bandung: Yrama Widya Sugiyono. (2014). Metode Penelitian Kualitatif, Kuantittaif dan $R \& D$.Bandung: Alfabeta.

Surya, M. (2015). Strategi Kognitif dalam Proses Pembelajaran.Bandung: Alfabeta.

Tarigan, H. Guntur. (1979). Menulis Paragraf dan Pengembangannya.Bandung: Angkasa.

Tarigan, H. Guntur. (1983). Menulis Sebagai Suatu Keterampilan Berbahasa. Bandung: Angkasa.

Trianto. (2007). Model-model Pembelajaran Inovatif Berorientasi Konstruktivistik. Jakarta: Prestasi Pustaka

Wiyanto, A. (2004). Terampil Menulis Paragraf. Jakarta: Gramedia Widiasarana Indonesia

Zainurrahman. (2011). Menulis : Dari Teori Hingga Praktik (Penawar Racun Plagiarisme). Bandung: Alfabeta. 